\title{
IMPORTANCE OF CAROTID INTIMA MEDIA THICKNESS IN CHILDHOOD OBESITY
}

\author{
M. Vijayakumar' 1 S. Sabitha², K. Princy33, V. R. Rajendran 4, A. V. Goplan ${ }^{5}$ \\ ${ }_{1}^{1}$ Associate Professor, Department of Paediatrics, Government Medical College, Kozhikode, Kerala. \\ ${ }^{2}$ Assistant Professor, Department of Paediatrics, Government Medical College, Kozhikode, Kerala. \\ 3Junior Resident, Department of Paediatrics, Government Medical College, Kozhikode, Kerala. \\ 4 Professor, Department of Radiology, Government Medical College, Kozhikode, Kerala. \\ 5 Professor, Department of Paediatrics, Government Medical College, Kozhikode, Kerala.
}

\section{ABSTRACT}

\section{BACKGROUND}

Obesity is increasing at a rapid pace in developing countries because of life style transition. Carotid intima media thickness is a marker of coronary heart disease in adults.

Aim of this study is to find out the correlation of carotid intima media thickness with the usual measures of childhood obesity like waist circumference, waist-hip ratio and also with abdominal fat indices and lipid profile

\section{MATERIALS AND METHODS}

75 obese children and 50 age and sex matched controls between 5-12 years attending Paediatric Endocrinology Clinic in Government Medical College, Kozhikode, Kerala were included. Abdominal fat thickness and fatty liver were measured by abdominal ultrasound and intima media thickness of both carotid arteries were measured at $2 \mathrm{~cm}$ before the bifurcation of common carotid artery. Statistical analysis was performed by using SPSS version 18.

\section{RESULTS}

Abdominal fat indices and carotid intima media thickness were higher in obese children compared to controls. Carotid intima media thickness had positive correlation with waist circumference, abdominal fat indices, systolic pressure, fasting blood sugar and total cholesterol in obese children

\section{CONCLUSION}

Carotid intima media thickness is a definitive screening method for evaluating cardiovascular risk in obese children.

\section{KEYWORDS}

Childhood Obesity, Carotid Intima Media Thickness, Waist Circumference, Waist-Hip Ratio.

HOW TO CITE THIS ARTICLE: Vijayakumar M, Sabitha S, Princy K, et al. Importance of carotid intima media thickness in childhood obesity. J. Evolution Med. Dent. Sci. 2017;6(7):586-591, DOI: 10.14260/Jemds/2017/125

\section{BACKGROUND}

Childhood obesity affects both developed and developing countries and all socio-economic groups irrespective of age, sex and ethnicity. Over 22 million under 5 children are obese and one child out of ten are overweight.(1) In India, all the available studies indicate that prevalence of overweight in Indian children between ages $5-17$ is $10 \%$.(2) The present pandemic of childhood obesity is due to life style changes. Obesity is an independent risk factor for coronary artery disease and Type 2 diabetes. ${ }^{(3)}$

Body Mass Index (BMI) is recognised as the gold standard in diagnosing and categorising childhood obesity. But it is a less sensitive index of fatness since it is a measure of excessive weight relative to height, rather than excess body fat.(4) Pattern of fat distribution influences cardiovascular risk. Abdominal obesity predicts cardiovascular risk better than BMI. Hence, waist circumference has a better association with the risk for coronary heart disease.(5)

Financial or Other, Competing Interest: None.

Submission 15-12-2016, Peer Review 08-01-2017,

Acceptance 14-01-2017, Published 23-01-2017.

Corresponding Author:

Dr. M. Vijayakumar

House No. 13/1831

Visakham, Near Silver Hills Public School,

Paroppady, Marikunnu P. O., Kozhikode-673012, Kerala.

E-mail: drmvijaycalicut@gmail.com

DOI: $10.14260 /$ jemds $/ 2017 / 125$

\section{(c) $(1) €$}

Carotid intima media thickness provides an indirect method of assessing coronary heart disease. $(5,6)$ Obese children develop endothelial dysfunction with deposition of fatty streaks and fibrous plaques and they are at a greater risk of developing coronary heart disease during adult life.(7) Even though the health consequences of obesity are seen in adulthood, it could start earlier in childhood and track into adulthood. Children may be asymptomatic, yet they should be followed closely for preventing early coronary heart disorders, diabetes and other complications. ${ }^{(8)}$

\section{Aim of the Study}

To find out the correlation of carotid intima media thickness with usual measures of childhood obesity like waist circumference, waist-hip ratio and also with abdominal fat indices and lipid profile.

\section{MATERIALS AND METHODS \\ Subjects}

75 obese children and 50 age and sex matched controls between 5-12 years attending Paediatric Endocrinology Clinic in Government Medical College, Kozhikode, Kerala were included in this study.

\section{Study Setting}

Paediatric Endocrinology Clinic in the Institute of Maternal and Child Health, Government Medical College, Kozhikode, Kerala. 


\section{Study Period}

January 2014 - December 2015.

\section{Inclusion Criteria}

Children between 5 -12 years who had body mass index (BMI) above $95^{\text {th }}$ percentile in IAP BMI growth charts for age and sex constituted the obese group. Age and sex matched children attending the institute for minor illness constituted the control group.

\section{Exclusion Criteria}

Children with secondary obesity and very sick obese children were excluded from this study.

\section{Methodology \\ Anthropometric Measurements}

Height and weight were recorded and body mass index (BMI) was calculated in $\mathrm{kg} / \mathrm{m}^{2}$. The waist circumference was measured at the expiratory phase on the horizontal plane between the lowest margin of the $12^{\text {th }}$ rib and the mid portion of the superior iliac crest to the nearest $0.1 \mathrm{~cm}$ with a non-stretchable tape. Hip circumference was measured from the most protruding part of the hip to the nearest $0.1 \mathrm{~cm}$ with a non-stretchable tape.

\section{Blood Pressure}

Blood pressure was measured in sitting position in the right arm with a mercury sphygmomanometer. A cuff of width that encircles $40-50 \%$ of the upper arm was used. All subjects having a systolic and/or diastolic blood pressure higher than 95th percentile for age, sex and height were classified as having hypertension.

\section{Carotid Artery Ultrasound}

A longitudinal view of the distal common carotid artery was obtained from the suprasternal notch using a $7.5 \mathrm{MHz}$ sector transducer in supine position. The intima media thickness measurements were made in both carotid arteries at $2 \mathrm{~cm}$ before bifurcation. All measurements were done with the help of experienced radiologist.

\section{Abdominal Ultrasound for Abdominal Fat Thickness and Fatty Liver \\ Measurements were made using a $5 \mathrm{MHz}$ sector transducer. Subcutaneous fat thickness was measured from skin to anterior abdominal muscle. Visceral fat thickness from posterior abdominal muscle to abdominal anterior wall of aorta and pre-peritoneal fat thickness from the subcutaneous layer to the peritoneum. Fatty liver is graded as Grade 0- no fatty liver, Grade 1 -mild, Grade 2- moderate and Grade 3- severe.}

\section{Biochemical Analysis}

Fasting blood samples were obtained from all subjects and controls for measuring the levels of glucose, total cholesterol (TC), triglycerides (TG), low density lipoprotein cholesterol (LDL-C), and high density lipoprotein cholesterol (HDL-C). Serum glucose was measured by enzymatic spectrophotometric glucose oxidase method. Lipid parameters were determined by enzymatic methods using commercial kits.

\section{Statistical Methods}

Statistical analysis was performed using SPSS Version 18. Three statistical methods were used in this study. Chi-square test for gender distribution. Student's $t$ test for age, anthropometric parameters, clinical parameters, carotid intima media thickness, abdominal fat indices and biochemical parameters. The Pearson correlation coefficient for correlation between the carotid intima media thickness with age, anthropometric parameters, blood pressure, abdominal fat indices and biochemical parameters.

\section{RESULTS}

75 obese children and 50 age and sex matched controls were enrolled for the study. In the obese group, youngest child was 5 years old and oldest child was having 12 years of age. 38 children were boys.

\section{Anthropometric Data}

Waist circumference (WC) and Waist-Hip ratio (WHR) were significantly higher in obese group. Mean BMI was 24.50 . Waist circumference ranged from $63-103 \mathrm{~cm}$ with a mean value of $77 \mathrm{~cm}$. The mean WHR in these children was 0.93 . Anthropometric measurements of control group were well below the obese group with mean BMI of 14.78, WC of 45.72 and WHR of 0.88 .

\section{Blood Pressure}

Both systolic blood pressure and diastolic blood pressure were significantly higher in obese children. 13 obese children had hypertension of which 6 had systolic hypertension, 3 had diastolic hypertension and 4 had both systolic and diastolic hypertension.

\begin{tabular}{|c|c|c|c|c|c|}
\hline \multirow{2}{*}{ Parameters } & \multicolumn{2}{|c|}{$\begin{array}{c}\text { Obese } \\
\text { Group }\end{array}$} & \multicolumn{2}{|c|}{ Control } & \multirow{2}{*}{ P } \\
\cline { 2 - 5 } & Mean & $\begin{array}{c}\text { Standard } \\
\text { Devia- } \\
\text { tion }\end{array}$ & Mean & $\begin{array}{c}\text { Standard } \\
\text { Devia- } \\
\text { tion }\end{array}$ & value \\
\hline $\begin{array}{c}\text { Body mass } \\
\text { index }\end{array}$ & 24.50 & 3.11 & 14.78 & 1.98 & $<0.001$ \\
\hline $\begin{array}{c}\text { Waist circum- } \\
\text { ference }\end{array}$ & 77.09 & 8.33 & 45.72 & 4.57 & $<0.001$ \\
\hline $\begin{array}{c}\text { Waist-Hip } \\
\text { ratio }\end{array}$ & 0.93 & 0.03 & 0.88 & 0.01 & $<0.001$ \\
\hline $\begin{array}{c}\text { Systolic } \\
\text { blood } \\
\text { pressure }\end{array}$ & 107.2 & 11.8 & 95.2 & 6.7 & $<0.001$ \\
\hline $\begin{array}{c}\text { Diastolic } \\
\text { blood } \\
\text { pressure }\end{array}$ & 69.9 & 8.7 & 64.8 & 7.1 & $<0.009$ \\
\hline $\begin{array}{c}\text { Table 1. Comparison of Anthropometric Measurements } \\
\text { and Blood Pressure }\end{array}$ & \multicolumn{7}{|c|}{} \\
\hline
\end{tabular}

\begin{tabular}{|c|c|c|c|c|}
\hline \multirow{2}{*}{ Parameters } & \multicolumn{2}{|c|}{$\begin{array}{c}\text { Right Carotid Intima } \\
\text { Media Thickness }\end{array}$} & \multicolumn{2}{c|}{$\begin{array}{c}\text { Left Carotid Intima } \\
\text { Media Thickness }\end{array}$} \\
\cline { 2 - 5 } & $\begin{array}{c}\text { Pearson } \\
\text { Correlation }\end{array}$ & P Value & $\begin{array}{c}\text { Pearson } \\
\text { Correlation }\end{array}$ & P Value \\
\hline $\begin{array}{c}\text { Waist circum- } \\
\text { ference }\end{array}$ & 0.291 & 0.011 & 0.65 & 0.578 \\
\hline $\begin{array}{c}\text { Waist-Hip } \\
\text { ratio }\end{array}$ & 0.166 & 0.154 & 0.184 & 0.114 \\
\hline $\begin{array}{c}\text { yystolic blood } \\
\text { pressure }\end{array}$ & 0.296 & 0.010 & 0.081 & 0.492 \\
\hline $\begin{array}{c}\text { Diastolic } \\
\text { blood } \\
\text { pressure }\end{array}$ & 0.101 & 0.392 & 0.107 & 0.362 \\
\hline \multicolumn{5}{|c|}{$\begin{array}{c}\text { Table 2. Correlation between Anthropometric Parameters } \\
\text { and Blood Pressure with Carotid Intima Media Thickness } \\
\text { in Obese Children }\end{array}$} \\
\hline
\end{tabular}




\section{Carotid Ultrasonological Data}

Both right and left carotid intima media thickness (cIMT) were measured. Significantly higher carotid intima media thickness was found in obese children compared to the control group. The mean right cIMT in obese children was $0.485 \mathrm{~mm}$ and the maximum thickness was $0.9 \mathrm{~mm}$. On the left side, mean cIMT was $0.465 \mathrm{~mm}$ with a maximum thickness of $0.7 \mathrm{~mm}$. In the control group, mean right cIMT was found to be $0.340 \mathrm{~mm}$ and left cIMT was $0.320 \mathrm{~mm}$.

\section{Abdominal Ultrasonological Data}

In the abdomen, parameters measured were subcutaneous fat thickness (SFT), visceral fat thickness (VFT), preperitoneal fat thickness (PPFT) and fatty liver grading. There were statistically significant higher values of subcutaneous, visceral and pre-peritoneal fat thickness in obese children when compared to control group. $44 \%$ of obese children had fatty liver, but no fatty liver was seen in the control group. In obese children, subcutaneous fat thickness ranged from 28 $\mathrm{mm}$ to $33 \mathrm{~mm}$, visceral fat thickness ranged from $8 \mathrm{~mm}$ to 63 $\mathrm{mm}$, and pre-peritoneal fat thickness ranged from $11 \mathrm{~mm}$ to $58 \mathrm{~mm}$. In non-obese children, subcutaneous fat thickness ranged from $6 \mathrm{~mm}$ to $14 \mathrm{~mm}$, visceral fat thickness ranged from $19 \mathrm{~mm}$ to $35 \mathrm{~mm}$, and pre-peritoneal fat thickness ranged from $12 \mathrm{~mm}$ to $21 \mathrm{~mm}$.

\begin{tabular}{|c|c|c|c|c|c|}
\hline \multirow[b]{2}{*}{ Parameter } & \multicolumn{2}{|c|}{ Obese Group } & \multicolumn{2}{|c|}{ Control } & \multirow[b]{2}{*}{$\begin{array}{c}P \\
\text { value }\end{array}$} \\
\hline & $\begin{array}{l}\text { Mean } \\
(\mathrm{mm})\end{array}$ & $\begin{array}{c}\text { Standard } \\
\text { Deviation }\end{array}$ & $\begin{array}{l}\text { Mean } \\
(\mathrm{mm})\end{array}$ & $\begin{array}{c}\text { Standard } \\
\text { Deviation }\end{array}$ & \\
\hline Right cIMT & 0.485 & 0.12 & 0.340 & 0.05 & $<0.001$ \\
\hline Left cIMT & 0.467 & 0.09 & 0.320 & 0.40 & $<0.001$ \\
\hline $\begin{array}{l}\text { Subcutaneous } \\
\text { fat thickness }\end{array}$ & 19.1 & 4.6 & 10.1 & 2 & $<0.001$ \\
\hline $\begin{array}{c}\text { Visceral fat } \\
\text { thickness }\end{array}$ & 31.7 & 11.9 & 24.5 & 3.9 & 0.004 \\
\hline $\begin{array}{l}\text { Preperitoneal } \\
\text { fat thickness }\end{array}$ & 25.6 & 15.9 & 8.1 & 2.4 & $<0.001$ \\
\hline Fatty liver & 0.45 & 0.527 & 0 & 0 & $<0.001$ \\
\hline
\end{tabular}

Table 3. Comparison of Carotid and Abdominal Ultrasonological Data

\begin{tabular}{|c|c|c|c|c|}
\hline \multirow{2}{*}{ Parameters } & \multicolumn{2}{|c|}{$\begin{array}{c}\text { Right Carotid Intima } \\
\text { Media Thickness }\end{array}$} & \multicolumn{2}{|c|}{$\begin{array}{c}\text { Left Carotid Intima } \\
\text { Media Thickness }\end{array}$} \\
\cline { 2 - 5 } & $\begin{array}{c}\text { Pearson } \\
\text { Correlation }\end{array}$ & P value & $\begin{array}{c}\text { Pearson } \\
\text { Correlation }\end{array}$ & P value \\
\hline $\begin{array}{c}\text { Subcutaneous } \\
\text { fat thickness }\end{array}$ & 0.254 & 0.028 & 0.209 & 0.072 \\
\hline $\begin{array}{c}\text { Visceral fat } \\
\text { thickness }\end{array}$ & 0.325 & 0.004 & 0.362 & 0.001 \\
\hline $\begin{array}{c}\text { Pre peritoneal } \\
\text { fat thickness }\end{array}$ & 0.348 & 0.002 & 0.155 & 0.185 \\
\hline Fatty liver & 0.305 & 0.008 & 0.166 & 0.155 \\
\hline
\end{tabular}

Table 4. Correlation between Abdominal Fat Indices with
Carotid Intima Media Thickness in Obese Children

\section{Laboratory Data}

Fasting blood sugar was found to be higher in the obese children, even though the values were in the normal range. Total cholesterol, LDL cholesterol, and triglycerides were significantly higher in obese children. HDL cholesterol was significantly lower in this group.
To assess the relationship between anthropometric indices, blood pressure, abdominal fat indices and laboratory values on carotid intima media thickness, the Pearson product-moment correlation coefficient was used

Among the anthropometric indices, waist circumference showed a significant correlation with right cIMT. Systolic blood pressure had significant correlation with right cIMT while diastolic blood pressure did not show any correlation with cIMT. Among fat indices, visceral fat thickness had significant correlation with cIMT of both sides, while superficial fat thickness and pre-peritoneal fat thickness had good correlation with right cIMT. Fatty liver was significantly correlated with right cIMT. Among laboratory parameters, fasting blood sugar and total cholesterol values were having significant correlation with left cIMT

\begin{tabular}{|c|c|c|c|c|c|}
\hline \multirow[b]{2}{*}{ Parameter } & \multicolumn{2}{|c|}{ Obese Group } & \multicolumn{2}{|c|}{ Control } & \multirow[b]{2}{*}{ P Value } \\
\hline & Mean & $\begin{array}{l}\text { Standard } \\
\text { Deviation }\end{array}$ & Mean & $\begin{array}{l}\text { Standard } \\
\text { Deviation }\end{array}$ & \\
\hline $\begin{array}{c}\text { Fasting blood } \\
\text { glucose } \\
(\mathrm{mg} / \mathrm{dL})\end{array}$ & 79 & 10 & 73.1 & 5.4 & 0.007 \\
\hline $\begin{array}{c}\text { Total } \\
\text { cholesterol } \\
(\mathrm{mg} / \mathrm{dL})\end{array}$ & 180.4 & 27.7 & 137.4 & 9.5 & $<0.001$ \\
\hline $\begin{array}{c}\text { LDL- } \\
\text { cholesterol } \\
(\mathrm{mg} / \mathrm{dL})\end{array}$ & 110.4 & 23.1 & 72.4 & 9.7 & $<0.001$ \\
\hline $\begin{array}{c}\text { Triglycerides } \\
\text { (mg/dL) }\end{array}$ & 122 & 48.8 & 72.5 & 8 & $<0.001$ \\
\hline $\begin{array}{c}\text { HDL- } \\
\text { cholesterol } \\
(\mathrm{mg} / \mathrm{dL})\end{array}$ & 45.6 & 8.3 & 50.3 & 3 & 0.007 \\
\hline
\end{tabular}

Table 5. Comparison of Laboratory Data

\begin{tabular}{|c|c|c|c|c|}
\hline \multirow{2}{*}{ Parameters } & \multicolumn{2}{|c|}{$\begin{array}{c}\text { Right Carotid Intima } \\
\text { Media Thickness }\end{array}$} & \multicolumn{2}{|c|}{$\begin{array}{c}\text { Left Carotid Intima } \\
\text { Media Thickness }\end{array}$} \\
\cline { 2 - 5 } & $\begin{array}{c}\text { Pearson } \\
\text { Correlation }\end{array}$ & P value & $\begin{array}{c}\text { Pearson } \\
\text { Correlation }\end{array}$ & P value \\
\hline $\begin{array}{c}\text { Fasting blood } \\
\text { glucose }\end{array}$ & 0.148 & 0.204 & 0.256 & 0.027 \\
\hline $\begin{array}{c}\text { Total } \\
\text { cholesterol }\end{array}$ & 0.196 & 0.092 & 0.236 & 0.042 \\
\hline $\begin{array}{c}\text { LDL - } \\
\text { cholesterol }\end{array}$ & 0.128 & 0.272 & 0.203 & 0.081 \\
\hline Triglycerides & 0.209 & 0.072 & 0.087 & 0.045 \\
\hline $\begin{array}{c}\text { HDL - } \\
\text { cholesterol }\end{array}$ & 0.052 & 0.656 & 0.121 & 0.300 \\
\hline Table 6. Corr
\end{tabular}

Table 6. Correlation between Laboratory Parameters and Carotid Intima Media Thickness in Obese Children

\section{DISCUSSION}

The emerging pandemic of obesity, cardiovascular disease and diabetes is causing serious public health concern and contributes to 2.6 million deaths every year.(9) Obesity pandemic has significantly escalated the health care costs in the last 2 decades.(10) Obesity is an independent risk factor for cardiovascular disease and is associated with increased risks of early deaths and morbidity. ${ }^{(11,12)}$

In the present study, waist circumference was found to be significantly higher in the obese group. Waist circumference also showed a significant correlation with right carotid intima 
media thickness (CIMT), which is a marker of future cardiovascular risk.(13) Sava SC et al had shown that waist circumference has strong associations with the risk for coronary heart disease.(14) Panjikkaran ST(15) et al and Rebecca Kuriyan et al(16) had measured waist circumference in Indian school going children and had developed age and gender specific waist circumference reference data.(17)

The Waist-Hip ratio (WHR) is an index of regional adipose tissue distribution. In the present study, a significantly high WHR was seen in obese children, but it had no correlation with carotid intima media thickness. Pouliot et al demonstrated that WHR determines the regional distribution of adipose tissue, and is relatively independent of the degree of obesity.(18)

Obesity is a prominent risk factor in the development of hypertension(19) In the present study, both systolic blood pressure and diastolic blood pressure were significantly high in obese children.(20) Systolic blood pressure had significant correlation with carotid intima media thickness. A Turkish study noted systolic hypertension in $11.6 \%$ and diastolic hypertension in $19.6 \%$ in obese children.(21) In the present study, systolic hypertension was positively related to waist circumference which underscores the importance of maintaining an ideal waist circumference for preventing an elevated blood pressure.(22)

Carotid intima media thickness (cIMT) is associated with the risk of early development of atherosclerosis.(23) It can be measured in a simple, cheap and non-invasive way by using an ultrasound. Hence, it can be used in large scale population studies.(24) In 2001 Tounian et al reported that severe obesity in children was associated with impaired carotid distensibility. $(25,26)$ Similar results were recorded in the studies of Lannuzzi A et al and Woo et al.(27) The present study also demonstrated increase in cIMT in obese children when compared with age and sex matched control group.

Recently, many studies throw light to the importance of cIMT in children also, for predicting future cardiovascular risk. (28) But standard cut-off values in children are lacking. Limited studies are available and most of them are from developed countries.(29) These include studies from Belgium, Austria, Spain, Italy and Portugal.(30,31) The present study found a significantly higher cIMT in obese children.
The main limitation of published studies was the heterogeneity of ultrasound measurement protocols which could partially explain the wide ranges of cIMT values obtained. The present study measured intima media thickness in both carotid arteries at about $2 \mathrm{~cm}$ before bifurcation.

The present study also found that cIMT was positively correlated with waist circumference, systolic blood pressure, abdominal fat indices, fasting blood sugar and total cholesterol. Hence all major predictors for cardiovascular disease are found to be associated with an increase in cIMT in children. It is therefore useful to include carotid ultrasound assessment in screening evaluation of overweight children to identify those at high cardiovascular risk.

Abdominal visceral fat begins to accumulate in early childhood.(32,33) In the present study, there was a statistically significant higher values of subcutaneous, visceral and preperitoneal fat thickness in obese children even in the prepubertal age group. $(34,35,36)$

Prevalence of fatty liver increased progressively from children with normal weight to overweight and obese children, affecting almost $50 \%$ of obese children.(37,38) Fatty liver is considered to be the hepatic expression of metabolic syndrome. $(39,40,41)$ In the present study, $42.7 \%$ of obese children had Grade 1 fatty liver and $1.3 \%$ had Grade 2 fatty liver while no fatty liver was seen in the control group. Caserta et al found an overall prevalence of fatty liver in $12.5 \%$ of overweight children.(36)

In the present study, we found that fasting blood sugar was significantly higher in obese children even though the values were in the normal range. Total cholesterol, LDL cholesterol, and triglycerides were significantly higher in the obese children. HDL cholesterol was significantly lower in this group. ${ }^{(42,43)}$ A positive correlation between preperitoneal fat thickness had positive correlation with total cholesterol values. Present study showed that increase in total body fat leads to fat deposition in both subcutaneous and visceral areas. Goran et al reported that body fat in general is the predominant factor influencing insulin sensitivity. $(44,45,46)$

\begin{tabular}{|c|c|c|c|c|c|c|c|}
\hline \multirow{2}{*}{ Study } & \multirow{2}{*}{ Country } & \multirow{2}{*}{$\begin{array}{l}\text { Year of } \\
\text { Study }\end{array}$} & \multicolumn{2}{|c|}{ Subjects } & \multirow{2}{*}{$\begin{array}{l}\text { Age } \\
\text { Group }\end{array}$} & \multirow{2}{*}{\multicolumn{2}{|c|}{$\begin{array}{c}\text { Carotid Intima Media Thickness Mean } \\
\text { (Range) Obese } \quad \text { Control }\end{array}$}} \\
\hline & & & Obese & Control & & & \\
\hline $\begin{array}{c}\text { Iannuzi A } \\
\text { et al(47) }\end{array}$ & Belgium & 2004 & 100 & 47 & $6-14$ & $0.55(0.54-0.57)$ & $0.48(0.46-0.51)$ \\
\hline $\begin{array}{l}\text { Woo KS } \\
\text { et al(27) }\end{array}$ & China & 2004 & 36 & 36 & $9-12$ & $0.49(0.45-0.53)$ & $0.45(0.37-0.53)$ \\
\hline $\begin{array}{l}\text { Jourdan EW } \\
\text { et al } 47\end{array}$ & Germany & 2005 & 0 & 247 & $10-20$ & - & $0.39(0.38-0.40)$ \\
\hline $\begin{array}{c}\text { Kapiotis S } \\
\text { et al(47) }\end{array}$ & Austria & 2006 & 127 & 24 & $8-16$ & $0.37(0.33-0.41)$ & $0.34(0.31-0.37)$ \\
\hline $\begin{array}{c}\text { Beauloye } \mathrm{V} \\
\text { et al(47) }\end{array}$ & Italy & 2007 & 104 & 93 & $10-13$ & $0.47(0.39-0.55)$ & $0.43(0.35-0.51)$ \\
\hline $\begin{array}{l}\text { Nunez F } \\
\text { et al (46) }\end{array}$ & Italy & 2010 & 65 & 34 & $8-16$ & \multicolumn{2}{|c|}{ No difference in cIMT } \\
\hline $\begin{array}{l}\text { A Leite } \\
\text { et al }\end{array}$ & Portugal & 2012 & 50 & 50 & $10-18$ & 0.472 & 0.461 \\
\hline $\begin{array}{l}\text { Present } \\
\text { study }\end{array}$ & India & 2016 & 75 & 50 & $5-12$ & $\begin{array}{l}0.485(0.3-0.9)-\mathrm{Rt} \\
0.465(0.3-0.7) \mathrm{Lt}\end{array}$ & $\begin{array}{c}0.340(0.3-0.4) \mathrm{Rt} \\
0.320(0.3-0.4) \mathrm{Lt}\end{array}$ \\
\hline
\end{tabular}




\section{CONCLUSION}

Waist circumference and waist-hip ratio are significantly higher in obese children. These children have significantly higher fasting blood sugar, total cholesterol, LDL cholesterol, triglycerides and lower HDL compared to normal children. They have significantly high abdominal fat indices like subcutaneous fat thickness, visceral fat thickness, preperitoneal fat thickness and fatty liver. Carotid intima media thickness (cIMT) is significantly higher in obese children. cIMT is positively correlated with waist circumference, abdominal fat indices, systolic blood pressure, fasting blood sugar and total cholesterol. Among abdominal fat indices, visceral fat thickness has high correlation with cIMT in obese children. Waist circumference has significant association with carotid intima media thickness.

Hence, carotid ultrasound assessment is a definitive screening method in evaluating cardiovascular risk in obese children. Since waist circumference is having a significant correlation with cIMT, this simple diagnostic tool is a good predictor of atherosclerotic disease in children with obesity.

\section{Acknowledgements}

The authors acknowledge all the children and their parents who participated in this study.

\section{Contributions}

All authors involved in case taking and interviewing the subjects and their parents. VK was involved in data collection, analysis and writing and reviewing the manuscript.

\section{REFERENCES}

[1] Kosti RI, Panagiotakos DB. The epidemic of obesity in children and adolescents in the world. Cent Eur J Public health 2006;14(4):151-9.

[2] Bharadwaj S, Misra A, Khurana L, et al. Childhood obesity in Asian Indians: a burgeoning cause of insulin resistance, diabetes and sub-clinical inflammation. Asia Pac J Clin Nutr 2008;17(S1):172-5.

[3] Raj M, Sundaram KR, Paul M, et al. Obesity in Indian children: time trends and relationship with hypertension. Natl Med J India 2007;20(6):288-93.

[4] Marwaha RK, Tandon N, Singh Y, et al. A study of growth parameters and prevalence of overweight and obesity in school children from Delhi. Indian Pediatr 2006;43(11):943-52.

[5] Guven A, Ozgen T, Gungor 0, et al. Association between the corrected QT interval and carotid intima media thickness in obese children. J Clin Res Ped Endo 2010;2(1):21-7.

[6] Cole TJ, Bellizi MC, Flegal KM, et al. Establishing a standard definition for child overweight and obesity worldwide: international survey. BMJ 2000;320:12403.

[7] Reilly JJ, Dorosty AR, Emmett PM. Identification of the obese child: adequacy of body mass index for clinical practice and epidemiology. Int J Obes Relat Metab Disord 2000;24(12):1623-7.

[8] Ogden CL, Troiano RP, Briefel RR, et al. Prevalence of overweight among preschool children in the United States, 1971 through 1994. Pediatrics 1997;99(4).
[9] Chhatwal J, Verma M, Riar SK. Obesity among preadolescents and adolescents of a developing country (India). Asia Pac J Clin Nutr 2004;13(3):231-5.

[10] Ramachandran A, Snehalatha C, Vinitha R, et al. Prevalence of overweight in urban Indian adolescent school children. Diabetes Res Clin Pract 2002;57(3):185-90.

[11] Khadilkar VV, Khadilkar AV. Prevalence of obesity in affluent school boys in Pune. Indian Pediatr 2004;41(8):857-8.

[12] Kapil U, Singh P, Pathak P, et al. Prevalence of obesity amongst affluent adolescent school children in Delhi. Indian Pediatr 2002;39(5):449-52.

[13] Raj M, Kumar RK. Obesity in children and adolescents. Indian J Med Res 2010;132(5):598-607.

[14] Savva SC, Tornaritis M, Savva ME, et al. Waist circumference and waist to height ratio are better predictors of cardiovascular risk factors in children than body mass index. Int J Obes Relat Metab Disord 2000;24(11):1453-8.

[15] Panjikkaran ST, Kumari KS. Augmenting BMI and waist-height ratio for establishing more efficient obesity percentiles in school-going children. Indian J Com Med 2009;34(2):135-9.

[16] Kuriyan R, Thomas T, Lokesh DP, et al. Waist circumference and weight for height percentiles in urban South Indian children aged 3-16 years. Indian Pediatr 2011;48(10):765-71.

[17] Guo SS, Roche AF, Chumela WC, et al. The predictive value of childhood body mass index values for overweight at age 35 y. Am J Clin Nutr 1994;59(4):810-9.

[18] Pouliot MC, Despres JP, Lemieux S, et al. Waist circumference and abdominal sagittal diameter: best simple anthropometric indices of abdominal visceral adipose tissue accumulation and related cardiovascular risk in men and women. Am J Cardiol 1994;73(7):460-8.

[19] Rolland C, Rolland-Cachera MF. Tracking the development of adiposity from one month of age to adulthood. Annals of human biology 1987;14(3):21929.

[20] Whitaker RC, Wright JA, Pepe MS, et al. Predicting obesity in young adulthood from childhood and parental obesity. The new Eng J Med 1997;337(13):869-73.

[21] Morrison JA, Friedman LA, Gray-Mc GC. Metabolic syndrome in childhood predicts adult cardiovascular disease 25 years later: the Princeton lipid research clinics follow-up study. Pediatrics 2007;120(2):340-5.

[22] Li S, Chen W, Srinivasan SR, et al. Childhood cardiovascular risk factors and carotid vascular changes in adulthood: the Bogalusa heart study. The J of Am Med Assn 2003;290(17):2271-6.

[23] Bibbins-Domingo K, Coxson P, Pletcher MJ, et al. Adolescent overweight and future adult coronary heart disease. New Eng J Med 2007;357(23):2371-9. 
[24] Freedman DS, Mei Z, Srinivasan SR, et al. Cardiovascular risk factors and excess adiposity among overweight children and adolescents: the Bogalusa heart study. J Pediatr 2007;150(1):12-7.

[25] McGill HC, McMahan CA, Herderick EE, et al. Obesity accelerates the progression of coronary atherosclerosis in young men. Circulation 2002;105(23):2712-8.

[26] Kwiterovich PO. Recognition and management of dyslipidemia in children and adolescents. J Clin Endocrinol Metab 2008;93(11):4200-9.

[27] Woo KS, Chook P, Yu CW, et al. Overweight in children is associated with arterial dysfunction and intima media thickening. Int J Obesity 2004;28(7):852-7.

[28] National cholesterol education program (NCEP): highlights of the report of expert panel on blood cholesterol levels in children and adolescents. Pediatrics 1992;89(3):495-501.

[29] Juonala M, Viikari JS, Ronnemaa T, et al. Associations of dyslipidemias from childhood to adulthood with carotid intima-media thickness, elasticity, and branchial flow mediated dilatation in adulthood: the cardiovascular risk in young finns study. Arterioscler Throm Vasc Biol 2008;28(5):1012-7.

[30] Ford ES, Mokdad AH, Ajani UA. Trends in risk factors for cardiovascular disease among children and adolescents in the United States. Pediatrics 2004;114(6):1534-44.

[31] Cook S, Kavey RE. Dyslipidemia and pediatric obesity. Pediatr Clin N Am 2011;58(6):1363-73.

[32] Wajchenberg BL. Subcutaneous and visceral adipose tissue: their relation to metabolic syndrome. Endocr Rev 2000;21(6):697-738.

[33] Kim G, Caprio S. Diabetes and insulin resistance in pediatric obesity. Pediatr Clin N Am 2011;58(6):135561.

[34] Hannon TS, Rao G, Arslanian SA. Childhood obesity and type 2 diabetes mellitus. Pediatrics 2005;116(2):473-80.

[35] Sinha R, Fisch G, Teague B, et al. Prevalence of impaired glucose tolerance among children and adolescents with marked obesity. New Eng J Med 2002;346(11):802-10.
[36] Caserta CA, Pendino GM, Alikante S, et al. Body mass index, cardiovascular risk factors and carotid intima media thickness in a pediatric population in southern Italy. J Pediatr Gastroenterol nutr 2010;51(2):216-20.

[37] Weiss R, Capiro S. The metabolic consequences of childhood obesity. Best Practice and Research Clinical Endocrinology and Metabolism 2005;19(3):405-19.

[38] Semiz S, Ozgoren E, Sabir N. Body fat distribution in childhood obesity: association with metabolic risk factors. Indian Pediatrics 2008;45(6):457-62.

[39] Schwimmer JB, Deutsch R, Kahen T, et al. Prevalence of fatty liver in children and adolescents. Pediatrics 2006;118(4):1388-93.

[40] Wiegand S, Keller KM, Robl M, et al. Obese boys are at increased risk for nonalcoholic liver disease: evaluation of 16,390 overweight or obese children and adolescents. Int J Obes 2010;34(10):1468-74.

[41] Barlow SE. Expert committee recommendations regarding prevention, assessment and treatment of child and adolescent overweight and obesity: summary report. Pediatrics 2007;120(Suppl 4):S16492.

[42] Kissebah AH. Central obesity: measurements and metabolic effects. Diabetes Rev 1997;5:8-20.

[43] Li C, Ford ES, Mokdad AH, et al. Recent trends in waist circumference and waist-height ratio among US children and adolescents. Pediatrics 2006;118(5):e1390-8.

[44] Shankar J, Mohan G, Pariyarath R, et al. Visceral fat assessment in over nourished children by ultrasonography and its relation to anthropometry. Indian J Pediatr 2012;79(10):1338-41.

[45] Lorenz MW, Marcus HS, Bolts ML, et al. Prediction of clinical cardiovascular events with carotid intimamedia thickness: a systematic review and metaanalysis. Circulation 2007;115(4):459-67.

[46] Lamotte C, Lliescu C, Libersa C, et al. Increased intimamedia thickness of the carotid artery in childhood: a systematic review of observational studies. Eur J Pediatr 2011;170(6):719-29.

[47] Berenson GS. Childhood risk factors predict adult risk associated with subclinical cardiovascular disease. The Bogalusa heart study. Am J Cardiol 2002;90(10C):3L-7. 